RACAR : Revue d'art canadienne

Canadian Art Review

\title{
Anne Markham Schulz, The Sculpture of Bernardo Rossellino and his Workshop. Princeton, Princeton University Press, 1977. 176 + xxiii pp., 225 illus., \$35.00
}

\section{Debra Pincus}

Volume 5, numéro 1, 1978

URI : https://id.erudit.org/iderudit/1077333ar

DOI : https://doi.org/10.7202/1077333ar

Aller au sommaire du numéro

\section{Éditeur(s)}

UAAC-AAUC (University Art Association of Canada | Association d'art des universités du Canada)

\section{ISSN}

0315-9906 (imprimé)

1918-4778 (numérique)

Découvrir la revue

Citer ce compte rendu

Pincus, D. (1978). Compte rendu de [Anne Markham Schulz, The Sculpture of Bernardo Rossellino and his Workshop. Princeton, Princeton University Press, 1977. 176 + xxiii pp., 225 illus., \$35.00]. RACAR : Revue d'art canadienne /

Canadian Art Review, 5(1), 76-79. https://doi.org/10.7202/1077333ar

Tous droits réservés (C) UAAC-AAUC (University Art Association of Canada | Association d'art des universités du Canada), 1978
Ce document est protégé par la loi sur le droit d'auteur. L'utilisation des services d'Érudit (y compris la reproduction) est assujettie à sa politique d'utilisation que vous pouvez consulter en ligne.

https://apropos.erudit.org/fr/usagers/politique-dutilisation/ 
sion on the one hand, and that of Alexander the Great on the other. These illustrations, Restle informs us, seem to be in accordance with a text which has come down to us only in a Latin and an old French version (1264) and which was utilized by Dante in his Divine Com$e d y$.

There is a good bibliography and an appendix which includes a wellconceived glossary of technical terms abundantly illustrated with drawings. These give special value to the book. Dispersed throughout the text are beautiful lithographs and engravings taken from early nineteenth-century publications of western travellers to the East. They recall Byron's Childe Harold and Don Juan, Lamartine's Voyage en Orient, and the later writings of Loti. Reading the book and pondering on the engravings, we become aware that there is always room for mystery in the old sites of the East. The author deserves our admiration and the publishers our praise for producing a book unique among its kind. It will, one hopes, be widely translated.

GEORGE GALAVARIS McGill University Montreal

Images of Love and Death in Late Medieval and Renaissance Art. The University of Michigan Museum of Art. 2 I Nov. 1975-24 Jan. 1976 Essays by Clifton C. Olds and Ralph G. Williams; Catalogue by William $\mathrm{R}$. Levin. Ann Arbor, University of Michigan, 1976. 132 pp., 68 illus.

Voici un catalogue d'exposition admirablement exécuté et présenté, sur quelques-uns des thèmes fondamentaux de la fin du Moyen Âge et de la Renaissance, ceux qui tournent autour de l'Amour et de la Mort. L'illustration est abondante et elle met en valeur des œuvres nombreuses conservées dans plusieurs musées américains. On passe des manuscrits, aux premières gravures, aux dessins et peintures, aux tapisseries et tissus, aux ivoires, aux objets de métal, aux bijoux et coffrets. Plusieurs maîtres italiens $y$ sont représentés à côté des artistes de l'Europe du Nord depuis le début du XIV siècle jusqu'au $X^{e} I^{e}$ siècle avancé. Le catalogue de William R. Levin est particulièrement riche: il fait chaque fois le point sur la provenance et le style des œuvres, sur les thèmes représentés et leurs sources historiques ou artistiques. Le texte est toujours dense et très pertinent. Il renvoie à une copieuse bibliographie dressée à la fin.

Deux textes, auparavant, introduisent globalement les thèmes de l'Amour et de la Mort dans l'art (Clifton C. Olds) et dans la littérature (Ralph G. Williams). Le texte sur la littérature est particulièrement intéressant. L'auteur nous fait faire un parcours rapide, mais très clair depuis Hésiode et Platon jusqu'à Dante, Boccace et le néoplatonisme de la Renaissance en passant par Rome et par l'amour courtois médiéval. Fort habilement, l'auteur apporte d'assez longues citations de divers auteurs pour appuyer les diverses conceptions de l'Amour et de la Mort et pour nous faire entrer d'emblée dans l'ambiance même du Moyen Âge et au cœur des théories nombreuses qu'ont élaborées les spécialistes sur tous ces sujets.

Le texte de Clifton C. Olds est plus court et quelque peu décevant. Il était d'ailleurs difficile de faire le bilan d'œuvres très variées et même disparates de style (ivoire du début du XIve siècle, gravure de Dürer, dessins italiens), déjà étudiés ailleurs dans leur contexte respect if et rassemblées ici pour leur seule affinité iconographique. C'est vraiment l'inconvénient de ce genre d'exposition de déboucher sur des considérations globales de portée éventuellement plus historique que proprement artistique. Dans cette veine, l'auteur aurait pu évoquer davantage certains aspects de la vie au Moyen Âge autres que la peste noire de 1348 , présenter quelquesunes des œuvres si nombreuses conservées dans divers monuments d'Europe comme la sculpture funéraire, les fresques, etc. Mais dans l'ordre des idées générales, l'auteur va certainement à l'essentiel lorsqu'il affirme que les regards et gestes des amoureux des $\mathrm{Xv}^{\mathbf{e}}$ et $\mathrm{XVI}^{\mathrm{e}}$ siècles expriment la promesse de félicités à venir plutôt que l'emportement de la passion. L'homme occidental aurait-il toujours été en quête d'un paradis toujours lointain? Chacun pourra comparer les images offertes par ce répertoire avec l'art amoureux des Indes ou du Japon pour s'en convaincre un peu.

ROLAND SANFAÇON Université Laval Québec

ANNE MARKHAM SCHULZ The Sculpture of Bernardo Rossellino and his Workshop. Princeton, Princeton University Press, 1977.1 $76+$ xxiii pp., 225 illus., $\$ 35$.oo.

Bernardo Rossellino has not yet had the kind of critical monograph that has been accorded most of his contemporary Florentine artists. Active as both architect and sculptor, and in both spheres overshadowed by more attractive and more charismatic personalities Alberti in the field of architecture, Donatello and Ghiberti in sculpture - it has been difficult to sort out the exact nature of his contribution to the early Renaissance. The most comprehensive work on Bernardo to date - a work that gives equal consideration to both his architecture and his sculpture - is Maryla Tyszkiewicz's Bernardo Rossellino (Florence, 1928), written in Polish and published in an edition of about one hundred copies. (An English translation of Tyszkiewicz's text, prepared under the direction of Schulz, is to be found in the Kunsthistorisches Institut, Florence.) It is a rather reverential study, elegantly produced on laid paper with tipped-in photographs, extremely useful for its compendium of documents but not a work that places Bernardo in a welldefined critical niche. More recent scholarship tends to divide Bernardo into his architectural and sculptural personae: e.g., Leo Planiscig's Bernardo und Antonio Rossellino (Vienna, 1942), which concentrates on the sculpture of both Bernardo and his extremely gifted younger brother; and now Schulz's monograph, a rigorous attempt to see Bernardo's sculptural production with clarity and historical perspective. 
The book is organized around nine extant works which Schulz has isolated as the sculptural commissions in which Bernardo was involved to a sufficient degree to be able to term them products of the Bernardo Rossellino workshop. Documents link Bernardo to seven of these commissions. Another commission, the tomb of Giovanni Chellini in the church of $S$. Domenico at S. Miniato al Tedesco just outside Florence, has been associated with Bernardo in the literature, and the connection is maintained here on the basis of 'formal resemblances.' From the standpoint of the development of fifteenthcentury sculpture, the most important work treated in the book is the tomb of Leonardo Bruni, the chancellor of Florence, in S. Croce, again a case in which documents do not exist to support the attribution, but where a solid Florentine tradition, stretching back to the sixteenth century, names Bernardo as the artist. Schulz devotes a chapter to each of the nine commissions. A separate catalogue appendix gives technical information and bibliography for each commission and another appendix gives transcriptions of relevant documents.

Born in about 1409 at Settignano, the site of important quarries, Bernardo begins his independent sculptural activity in 1433. He executes the now lost Sacrament tabernacle for the Benedictine Badia of SS. Fiora e Lucilla in Arezzo, and in the same year receives a plum of a commission: the façade sculpture for the Palazzo della Fraternità in Arezzo, including a large relief of the Virgin of Mercy and two figures in niches the first of the nine commissions dealt with by Schulz. But these, as well as another Sacrament tabernacle prepared in $143^{6-38}$ for the Badia of Florence (extant fragments, including a supporting eagle console, walled up in the Chiostro degli Aranci of the Badia) are essentially sporadic involvements in the field of sculpture. It is not until 1446 that Bernardo's sculptural work becomes of real demand, and it is at this point that Schulz would see a shop set up in which some twelve assistants of varying expertise take on active rôles. The shop goes at full speed for about five years - late 1446 through $145^{1-}$ and continues to exist in some form into the early 1460 , though with Bernardo no longer the dominating artistic personality. In an interesting introductory chapter, Schulz argues that Bernardo's sudden success as a sculptor has a great deal to do with a shift in taste in Florence away from the monumental figure and towards a more utilitarian class of sculpture that one can term church furniture, a shift initiated and encouraged by the economic straits of the 1430 .

What Bernardo had to offer was a product in which the architectural element was a major aspect of the piece. Portals and tabernacles were very much his line of work, and the shop established a corner on the sculptural market in the area of tomb production. The 1440 s and $145^{\circ}$ are an intriguing period in the history of tomb sculpture, for it is at this point that one finds a significant increase in the number of monumental tombs commissioned by private citizens. Families that would put money into large altars or fresco cycles now turn to costly tomb projects, and even, as in the case of the Beata Villana tomb commissicned from Bernardo in $145^{1}$, to the redoing of tombs of ancestors on a larger and grander scale. The Signoria itself, evidence suggests, becomes finally convinced during this period of the propaganda value of the large-scale sculptural tomb. It is in the late 144 os that Bernardo's shop - very likely in the employ of the state prepares the impressive Bruni tomb, perhaps the most important non-ecclesiastical tomb of the first half of the fifteenth century. Where Bernardo stood in all of this is clearly indicated by the fact that five of the nine commissions dealt with in this book are tomb commissions. Quite apart from what it does for our understanding of Bernardo Rossellino, Schulz's book is invaluable for the information it contributes towards our understanding of the Renaissance tomb.

The author, however, is in firm pursuit of another goal, the "classification according to hands of the individual portions of all the monuments and identification of one of those hands with the master of the shop.' Nothing so simple here as the assigning of figures to different masters, but a thoroughgoing analysis of every sculptural component placed against a rigor- ous standard of quality. The sculptural surfaces in the selected commissions are subjected to a minute examination, resulting in a cataloguing of fold types, a rigidly formal analysis of physiognomy, and a precise noting of certain peculiarities of working method (such as the exact way in which an artist chooses to make his surface emphases or define contours by use of the drill). The methodology has a great deal to do with a technical aid that has transformed the connoisseurship of art history in the twentieth century - the widespread use of photographs. The part-bypart analysis of works presented here relates naturally to the use of the detail photograph which breaks the momument up into conveniently analysable sections, frozen for prolonged study. And with this methodology, perhaps of necessity, goes some of the cold efficiency of the technician. It is often startling to turn from the scrupulous dissection in the text to the excellent photographs and experience again the quiet grace of this particular moment in Florentine sculpture which the works in their wholeness allow one to see.

The close analysis brings the author to a view of how quattrocento sculpture was produced in at least one mid-fifteenth-century workshop that is considerably different from anything yet put forward in the literature. The making of sculpture becomes rather similar to the craft of buon fresco. Each figure is split up into a number of convenient segments and these are parcelled out to members of the shop. The master intervenes at certain points, either to present a segment that will serve as a model or to do a section that has particular expressive or iconographic significance.

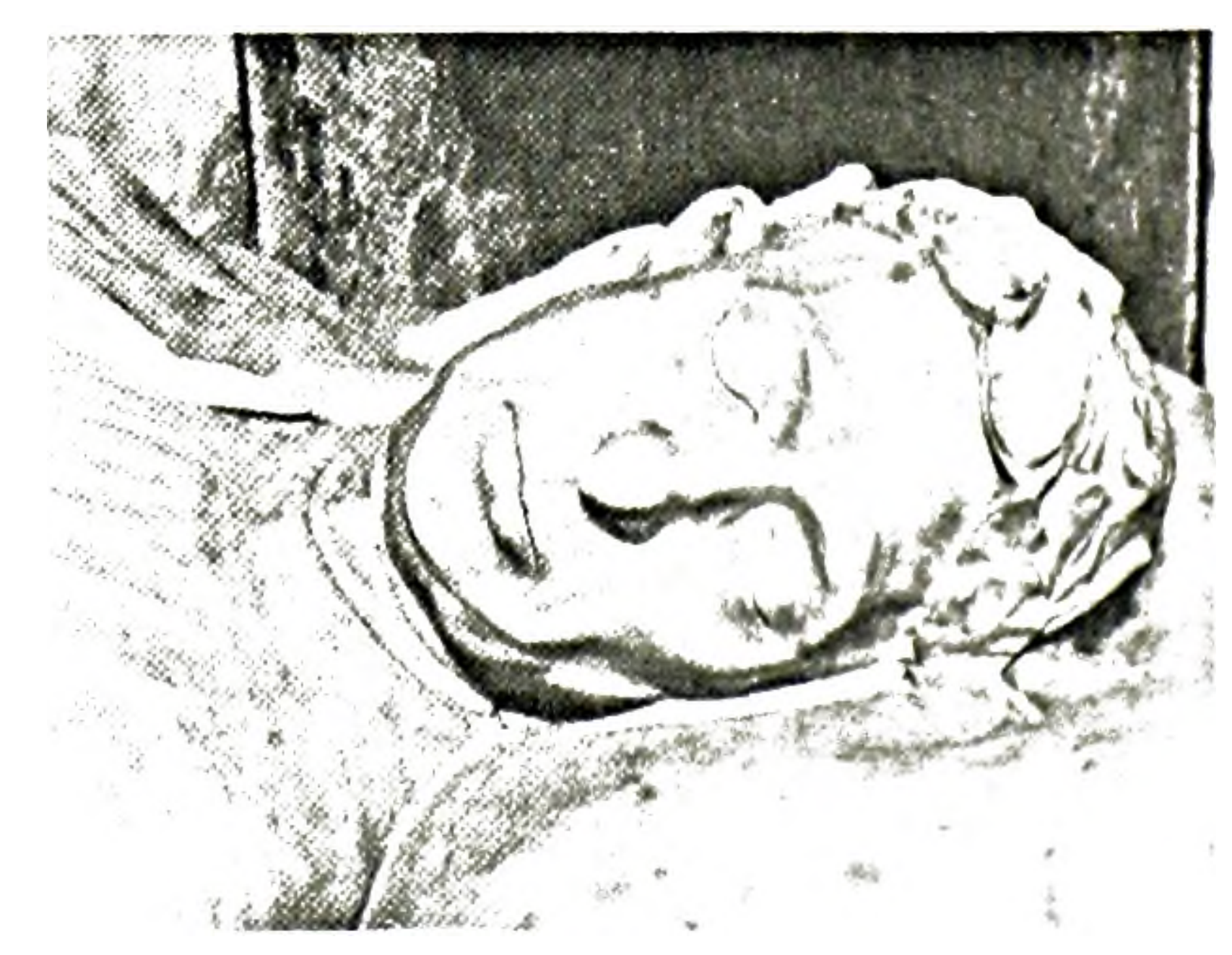

FIGURE 1. Bernardo Rossellino, Tomb of Leonardo Bruni (detail). From Schulz. 
Pieces often appear to have been worked on simultaneously by several assistants either because of limited workshop space or because of the pressures of time.

Schulz's proposal for piecemeal sculptural production is a controversial one and bound to attract a good many criticisms. As for Bernardo, the nominal subject of the book, the analysis leaves him denuded of anything resembling a personal ouvre. After the early façade sculpture of $1433-34$ for the Palazzo della Fraternità at Arezzo, executed prior to the formation of the shop, Bernardo's personal production is decidedly limited. No complete figure, with the exception of the miniature S. Egidio tabernacle angel, exists as an example of his mature style. He does seem to have had a flair for faces, this being an aspect of Bernardo's work that provides an interesting background for Antonio Rossellino's consummate handling of nuances of expression. Bernardo's facial type is established in the face of the Virgin at Arezzo, under the glaze of 143 os Florentine classicism. It emerges fully in the faces of the angel and the Virgin in the Annunciation group at Empoli of 1447 , with the reservation that the Virgin is seen as not having received a final finishing. This leaves the face of the Empoli angel, appropriately serving as the jacket illustration, and the portrait of the Bruni effigy (Fig. 1) as the two principal examples of Bernardo's fully conceived sculptural style.

Bernardo has not generally been seen as a major artistic hand, but if Schulz's conclusions are accepted his contribution to Renaissance sculpture would be rather precisely defined as that of designer and entrepreneur. I am largely convinced by the author's reductionist approach to Bernardo, but I would like to emphasize that it involves a number of a priori convictions and is at heart far more intuitive than the fold-by-fold analysis of the text might lead the reader to think. In order to isolate Bernardo's style within the shop, Schulz has created a hypothetical model, that of a first-class sculptor who would reveal in his work both the training of Ghiberti and the powerful influence of Donatello. In practical terms, this means that the individual pieces are not only analysed for stylistic consistency but are held

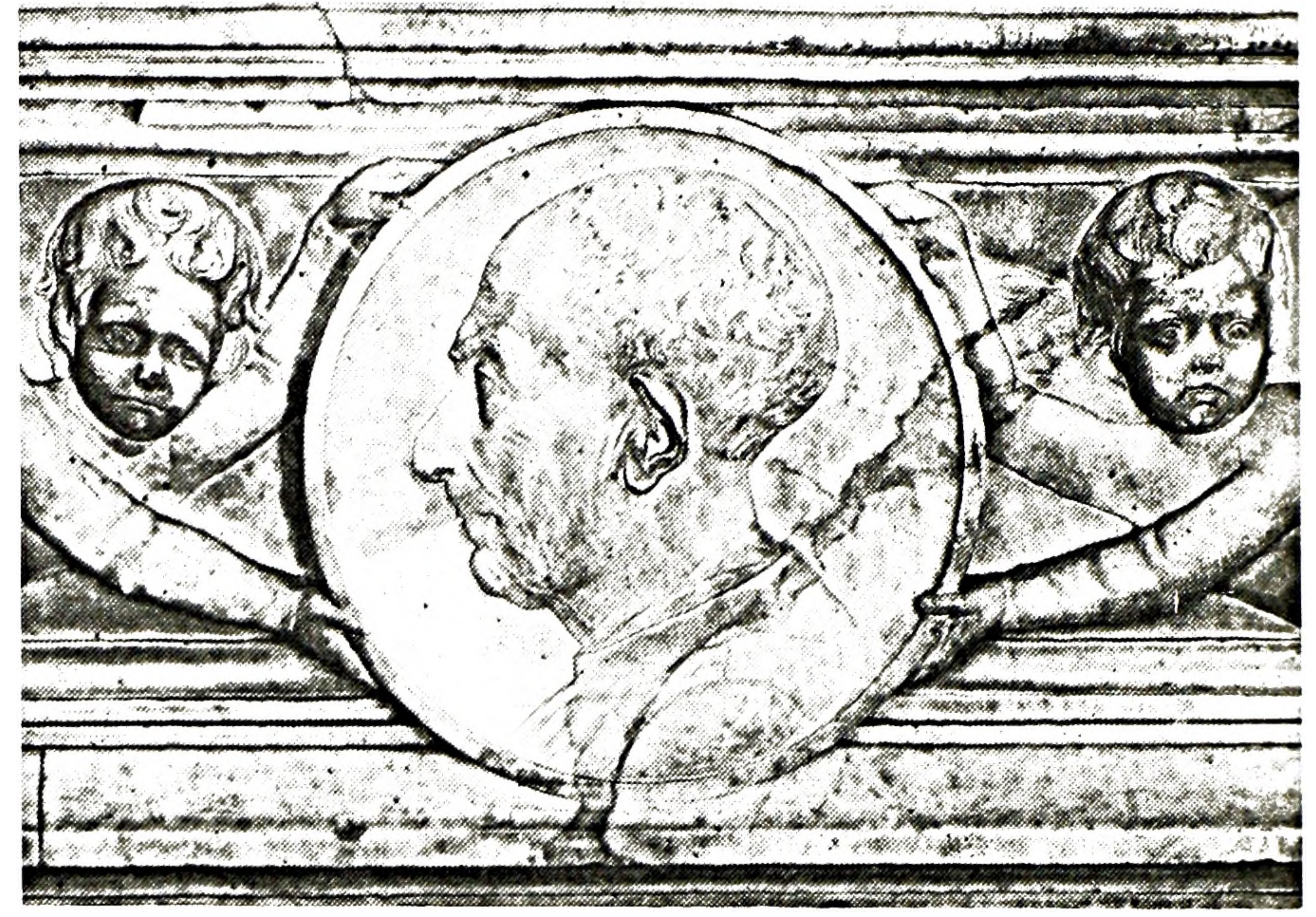

Figure 2. Antonio Rossellino, Portrait Medallion, Tomb of Neri Capponi. From Schulz.

up against the standard of what the author considers 'finest' at this particular artistic moment - the standard of a correct Florentine figure type of 'emphatic plasticity' and convincing movement, coming for the most part out of Donatello. There is a serious question as to how broadly the methodology can be applied to the analysis of Renaissance sculpture. If it work anywhere it works in Florence, where by the mid-fifteenth century there was an unusual degree of unanimity regarding the direction in which sculptural excellence lay, and where individual styles represented modifications within a generally accepted mode so that collaboration of the kind Schulz postulates becomes feasible.

With Bernardo as a sculptor demoted to a position of minimal importance, it is Antonio Rossellino and the young assistant Desiderio da Settignano who step forward as the founders of the sculptural style of the second half of the fifteenth century. It seems only appropriate that the commonly used surname Rossellino comes from a nickname evidently coined for Antonio, the 'little redhead.' The separating out of the styles of Anontio and Desiderio shows how effective Schulz's methodology can be with artists who have well-defined and consistent individual approaches. We see the two young sculptors working side by side on the long, hanging sleeves of the Bruni effigy. Antonio's particular feeling for heavy, three-dimensional cloth comes through well in Bruni's left-hand sleeve - on the side turned towards the viewer - and is clearly something different from Desiderio's tendency to reduce the substance of matter, treating the cloth of the right-hand sleeve as strip folds that sink back against the figure in a planar effect. The book's most important contribution to our picture of Renaissance sculptural styles lies, I believe, in its defining the early work of Antonio and Desiderio. Schulz shows us a Desiderio who is able to de-emphasize the volume of the figure without loss of convincing physicality. In Alberti's terms, it is circonscriptione winning out over modelling, and Schulz's sensitive analysis of Desiderio suggests that the style of contour, that style which has its most brilliant flourishing in the sixteenth century with Pontormo, may be an alternative Florentine manner as early as the 1440 .

The early Antonio also emerges from the book in a recognizable way. He is seen in a full figure almost entirely by his hand, in the left-hand genius of the Bruni tomb, where Bernardo's early classicism is already on its way to being transformed into the idealized classicism of Antonio's mature style. One of Antonio's most distinctive pieces while still working in his brother's 
shop is the portrait medallion of Neri Capponi (Fig. 2). Following Planiscig, Schulz very effectively compares the medallion to Antonio's signed and dated portrait bust of Giovanni Chellini of $145^{6}$ in the Victoria and Albert Museum. We are given a beautiful analysis of the portrait medallion which stresses Antonio's technical virtuosity. It is a virtuosity that will emerge fully developed in the 1460 s in works such as the Nori Madonna and that key momument of the second half of the fifteenth century, the tomb of the Cardinal of Portugal. Taking the conclusions of the book only slightly beyond what Schulz has provided, it may not be an exaggeration to say that Bernardo's most impressive production as a sculptor was his brother Antonio.

DEBRA PINCUS University of British Columbia

egon verheyen The Palazzo del Te in Mantua: Images of Love and Politics. Baltimore and London, The Johns Hopkins University Press, 1977. $15^{6}+$ xvi pp., 84 illus., $\$ 22.5^{0}$.

This volume is 'little' only in thickness, not in its intellectual density. In an epoch when archival research is as obligatory as it has been fashionably trivialized, it is a relief to find precise summaries of information contained in documents presenting, for the most part, no particular problems of formulation or nomenclature. Greater issues are clarified or introduced with economy, while fastidious accumulations of references not borne out by extant documentation are rejected except when some principle is at question. Verheyen's discussion accordingly unfolds as an unusual example of rigorous choice of subject and approach prior to research and development.

The discussion of principles naturally involves received ideas and interpretation founded upon the amount and nature of information available at any given period. As a result, principles may consciously be placed where they must needs be, as the foundations of critical fabric, as determinants rather than incidental considera- tions grafted onto the trunk of History. Preoccupations of other epochs are not ours and, moreover, do not readily lend themselves to the current demand for symmetrical conclusions of 'incontrovertible' nature, results which might surpass the exegete just as the original problems often surpassed contemporaries. A number of issues here raised are neither comfortably resolved to the point of equilibrium or expressional formulae; nor are they apt to be other than disturbing in their seeming candour

What if we were to accord inscriptions (placed by order of the patron, often situated in part of the oldest building fabric, and which form no visually incidental detail in the decoration) as some real indication of a general programme: FEDERICVS GONZAGA II MAR. V S.R.E./ ET REIP. FLOR. CAPITANEVS GENERALIS / HONESTO OCIO POST LABORES AD REPARANDAM / VIRT. QVIETI CONSTRVI MANDAVIT. What if a survey of the documentation for the series of ingenious chambers and dependencies executed from $15^{25} / 26-34$ on the Isola del $\mathrm{Te}$ suggests, among other things, that it was virtually impossible to maintain stylistic or conceptual homogeneity, save in a very general sense, because of changing circumstance? Had windows been established as functions of interior decorative schemes (pp. 11-12), how could these equally serve the much-discussed courtyard façades of what originally was a villa suburbana - if only by its location - that eventually became a palace conditioned by and incorporating all prior structures? (The crucial early view of the structure is best appreciated in the colour reproduction, Römisches Jahrbuch für Kunstgeschichte, XII [1969], p. 165 , fig. 4.) It is to be remarked that the impression of architectural regularity and symmetry is implicit in motif, e.g. the north façade, but not by any objective measure. Further, that an impressive argumentation can be made for the tapering off of activity from campaign to campaign, culminating in the virtual abandonment of interior decoration after the adoption of more expedient techniques than stucchi. Were this accepted, the willed and eccentric Mannerism defined in Pevsner's essay 'The Architecture of Mannerism' (1946) would be considerably infirmed - and, with it, the keystones to an entire exegetical approach inconsiderately extrapolated to other contexts since that date.

One may regret the concision of Verheyen's analysis of the mustica designs (pp.47-48). This, admittedly, is no immediate consideration within the history of the Te as designed and executed by Giulio Romano, since it lends itself to extensive theoretical discussion on the basis of the evidence offered. The Te is constructed of stucco over brick, and the continual visual and intellectual alternance of ars and natura is explicit in the façades, just as it is implicit in the renderings of the Strada drawings of $1567 / 68$ (Art Bulletin, xLIX [1 967 ], figs. 2-5): the 'falling triglyphs' on the east and west of the court are prevented by structural design from falling below a certain point, even as it is visually apparent that they would never reach that point. Art has anticipated the ruinous effects of Nature and forestalled them (fig. 28), and this conceit is appropriately contrasted with the orthodox treatment of the northsouth court axis. The Manneristic tendency to juxtapose, or, more properly speaking, to superimpose visual and historical memory of Renaissance theory and practice finds a splendid and personal statement in this its proper place.

In like manner, the organization of this study rightly supposes a threefold restatement, albeit in different context and emphasis, of: interpretation cum exposition; a catalogue raisonné of architectural and decorative schemes and motifs, along with their surviving evidence (pp. 107-32); and only then the documents themselves (pp. 133 45), these latter arranged chronologically, being further indexed by workers. Unlike F. Hartt's Giulio Romano (2 vols., 1 958), these are not limited 'almost exclusively to the publication of documents in which Giulio's name appears,' and afford new insights into the nature of workshop practice and the use of drawings (pp. 49-5o). In them, we come to understand the lack of certain types of documents as well as the proper usage of others, when essential discussions were doubtless of oral nature and never put down.

The Palazzo del Te provides food for thought at many levels. Al- 